\title{
WATER-SAVING AMONG SCHOOL STUDENTS IN MALAYSIA
}

\author{
Mohmadisa Hashim*, Mohamad Danial Mohd Shariff, Hanifah Mahat, \\ Saiyidatina Balkhis Norkhaidi, Nasir Nayan, Yazid Saleh \\ Universiti Pendidikan Sultan Idris, Malaysia \\ *e-mail: mohmadisa@fsk.upsi.edu.my
}

\begin{abstract}
A study was conducted among school students in Baling district, Kedah to study their level of knowledge, attitude, and practice regarding water-saving. A quantitative approach was adopted by survey instrument. The study sample consisted of 144 students, selected based using simple random sampling technique while stratified random technique was used to select school. Pearson's correlation and $t$-test were used used to analyse the data. Based on the findings, it was found that the level of knowledge and the level of attitude were high in water-saving, while the water-saving practice was at a moderate level. The t-test results showed that knowledge, attitude, and practice did not have a significant difference in water-saving. The results of the Pearson's correlation showed a moderately positive relationship between the water-saving knowledge and water-saving practice and a moderately positive relationship between water-saving attitude and practice. Overall, it can be concluded that the students had a high level of knowledge and attitude in water-saving. However, water-saving practice was still at a moderate level, and students need to improve their water-saving practice from time to time.
\end{abstract}

Keywords: awareness, exposure, knowledge, attitude, practice.

\section{INTRODUCTION}

Water wastage is considered as common by the community, especially young people, and awareness of water-saving practice has also been decreasing over time (Çoban, Akpınar, Küçükcankurtaran, Yıldız, \& Ergin, 2011). According to Çoban et al. (2011), one of the factors that drive people to waste water supply is because the current generation is not given effective water-related education, either formal or informal, on sustainable water use in daily life. Not only that, the attitude of some of the current generation who do not take the practice of water-saving seriously has led to a crisis in clean water supply (Leng, Weng, Hui, \& Jahi, 2013; Mariapan, Mahat, \& Nayan, 2018).

Malaysia is a country with an equatorial climate and receives a significant amount of rainfall throughout the year, with an average of $3000 \mathrm{~mm}$ of rainfall per year. Malaysia is also rich in water resources, such as rivers, lakes, ponds, and groundwater and has 189 river basins contributing to water resources with an estimated 900 billion cubic metres per year (Leng et al., 2013). Water resources in Malaysia are often adequate and never run out, but due to climate change and population growth over time, usable clean water is running low. In addition, Malaysia is currently experiencing rapid population growth and growth in the economic development sector, with the aim of becoming a "New Industrial Country", which has also directly contributed to the increase in the use of daily water resources (Leng et al., 2013). Malaysia has also experienced rapid growth and development in the last three decades (Hadi, 2010). The drastic increase in the standard of living, in the population, the manufacturing sector, the agricultural sector and urbanisation, has led to a sharp increase in water demand and consumption over time. Consequently, the increase in population has also led to environmental degradation, a decline in the quality and quantity of clean water resources (Kelly \& Fong, 2015; Marinoski, Rupp, \& Ghisi, 2018).

The younger generation plays a very important role in the prudent use of water. In promoting water-saving practice to students, the National Water Service Commission (SPAN), one of the agencies responsible for water resources, has organised Kempen Jimat Air (Water-Saving Campaign) for school students. This is done to inculcate and instil awareness among school students on water-saving practice and, in fact, will be able to prevent them from wasting a large amount of water in their daily lives (Ali, 2019). Not only that, but SPAN has also been upgrading its efforts to reduce the population's 
per capita water consumption by 180 litres per day by the year 2020 through campaigns related to water-saving. In fostering the knowledge and practice of water-saving among school students, SPAN has planned to implement Sekolah Rakan SPAN (SPAN Partner School) for at least five schools in Malaysia. This Sekolah Rakan SPAN program teaches students to use water properly and prudently when bathing, washing vehicles and so on (Ali, 2019).

In addition to implementing the Sekolah Rakan SPAN program, educators also play a direct role in raising students' awareness of water-saving. The responsibility that educators have in school is to perform the task of producing responsible and knowledgeable generations regarding prudent use of water. In fact, this is the most effective way to shape individuals to become more responsible towards water resources through education (Aydogdu \& Cakir, 2016). Educators can also provide exposure in school subjects, such as geography, at the secondary school level. For example, under the theme Sumber (Resources), there is a sub-topic of Pengurusan Sumber (Resource Management), which is Water Resources (Ministry of Education Malaysia, 2015). The early exposure given to school students is aimed at producing a generation that is aware of the worsening water issue and thus develops a high awareness of water-saving practice. Therefore, the purpose of this study is to study water-saving among school students, particularly the Form Six students, which covers the aspects of watersaving knowledge, attitude and practice in the Baling district, Kedah.

\section{Knowledge of Water-Saving}

Knowledge of water resource management is tied up with students' understanding of conservation, and the importance and knowledge of water-saving methods for the benefit of the global community (Yeap, Wahyuni, Khar, Cheah, \& Devadason, 2007). Knowledge and understanding of water issues in the community is considered a key element in solving water crisis problems (Dean, Fielding, \& Newton, 2016). There are several researchers who have done research on water-saving knowledge among school students. Mokmin \& Ithnin (2016), in their study of water-saving knowledge among school students, found that it was still only at a moderate level. The study was conducted at SMK Sultan Abdul Aziz, Kuala Selangor, Selangor. The results of the survey and analysis showed that the students' knowledge level was at a high level with 109 people (64.5\%), knowledge at the medium level recorded a total of 58 people $(34.3 \%)$ while there were only two people with a low level of knowledge (1.2\%).

Meanwhile, Mariapan et al. (2018) stated that knowledge of water use among students was still high and good. This study was conducted on Form Four students in the Kinta Utara district, Perak. The findings showed that the level of water-saving knowledge was at a high level with a majority of 311 students (74.0\%), at a medium level with 108 students $(25.7 \%)$ and at a low level with only one student ( $2 \%)$. Therefore, it can be concluded that, in order to increase students' water-saving knowledge, measures should be taken in terms of water-saving education through curriculum and co-curriculum so that students will continue to carry out water-saving practice in their daily lives.

\section{Attitude towards Water-Saving}

Ajzen (2005) defined attitude as the natural characteristics of one's thinking and attitude in responding, either agreeing or disagreeing with an object, person, institution, or event. Knowledge in water-saving can deeply influence the attitude of a community to avoid the ongoing water crisis and to practice water-saving (Wang, Chang, \& Liou, 2019). Therefore, students' attitude towards water-saving plays a major role in managing water sustainably. Studies at the university and college level have also been conducted by several international researchers to look at water conservation attitudes among students.

A study by Onyenankeya, Caldwell, \& Okoh (2015) was conducted regarding the attitude of college students towards water conservation at a leading university in the eastern region of South Africa, which involved 600 students. The results of the study showed that most students did not care about the conservation of water resources. Although $80.5 \%$ of the students agreed that water was important and must be maintained, a high percentage of these students did not consider water conservation as their responsibility. Not only that, $96.8 \%$ of the students did not see any pressure to conserve water. However, 
overall, nearly $99.5 \%$ of the students agreed that greater attention should be given towards water conservation, while $88.7 \%$ of the students also indicated that they could make more efforts to conserve water. Therefore, water conservation measures still need to be taken seriously among students so that water-saving measures can be maximised, water resources can be maintained in the long run, and water resource crises can be prevented.

\section{The Practice of Water-Saving}

Practice means how a person acts towards something, using methods, techniques, strategies, and procedures (Lambert, 2010). The practice of water-saving is something that is required of all groups of people, especially students, to avoid continuous wastage of water. A study by Mariapan (2018) found that students were still at a moderate level $(M=3.58)$ in the sustainable use of water in their daily lives. Overall, this study explained that the students' water-saving practice $(M=4.00)$ was at a high level. The results of the study also found that most students were at the moderate level of $57.1 \%$ water usage, while $42.4 \%$ of the students recorded a high level and 5\% were at a low level. Ironically, it showed that students were still not able to adopt maximum water-saving practices in their daily activities.

Keramitsoglou \& Tsagarakis (2011) also conducted a study on water-saving awareness among students and parents in Didimoticho, in the north east area of Greece. This study also explored the interactions between students and parents in using the latest water-saving technology and adopting water-saving practice in everyday life. The results of the study clearly showed that the parents were adopting a more comprehensive eco-friendly approach to watersaving compared to their children. Moreover, water education programmes attended by parents and students could directly assist and change the practice of saving in their daily use of water. Students and family members seemed ready to adhere to the water-saving practices that required little effort, such as using a watersaving toilet pump and replacing leaked pipes.

However, there were some students who were still not able to abandon the habit of wasting water, which was turning on the shower to the maximum when cleaning the body.
Therefore, active parental participation in school programmes can generally encourage effective interaction among students and make it easier to change behaviour towards the sustainable use of water (Keramitsoglou \& Tsagarakis, 2011). Therefore, water-saving practice needs to be given extra emphasis to increase the knowledge in line with the attitude and practice about watersaving.

\section{Gender Roles in Water-Saving}

Studies on gender and the practice of sustainability often get the attention of researchers. Among them are Loughland, Reid, Walker, \& Petocz (2003), who explained that the involvement of teenagers in the environment is generally influenced by gender difference because the involvement of genders in sustainable behaviour is a very important matter. Aprile \& Fiorillo (2017); Briere (2010); Lamm, Lundy, Warner, \& Lamm (2016); Sadik \& Sadik (2014); Mariapan et al. (2019) explained that women were, in general, more responsible, and prudent in water usage than men. Hablemitoglu \& Ozmete (2010) revealed that women were often referred to as water managers because they often engage in water usage activities and always ensure adequate water for five basic domestic purposes: washing, cleaning, bathing, drinking, and cooking. Therefore, this indicates that more women practice water-saving methods compared to men.

However, both genders, male, and female, have responsibility for saving water in everyday life. Damanhouri, Al-Saleem, \& AlAli (2012), as based on their study conducted at a university in Jordan involving 320 people, particularly on the level of awareness regarding water, explained that the female gender had a lower level of awareness in practicing watersaving and water conservation than the male gender. This is because, women carry out more housework that requires them to use more water than men. Thus, as women carry out more housework which makes them use water more excessively, it resulted in them using more water and not practicing as much water-saving as men. Therefore, this study also examined the gender differences between male and female students in water-saving awareness.

This study will answer four research hypotheses, namely: 1) $H_{0}(1)$ : There is no 
significant difference in knowledge of watersaving based on gender among students; 2) $H_{0}(2)$ : There is no significant difference in attitude towards water-saving based on gender among students; 3) $H_{0}(3)$ : There is no significant difference in the practice of water-saving based on gender among students; 4) $H_{0}(4)$ : There is no significant relationship between the level of knowledge and water-saving practice; and 5) $H_{0}(5)$ : There is no significant relationship between the level of attitude and water-saving practice.

\section{METHODS}

\section{Study Design}

The study on the awareness of water-saving among Form Six students in the Baling district, Kedah, was conducted using the quantitative method, along with the use of a questionnaire form to complete this study. The variables that were focused on in this study included watersaving knowledge, attitude and practice in the Baling district, Kedah. The use of descriptive analysis of mean and standard deviation was applied to assess the students' level of awareness in water-saving, either high, medium, or low. A $t$-test was used to facilitate the assessment of the differences in knowledge, attitude, and practice of water-saving between genders, while the Pearson's correlation was used to examine the relationship between the three aspects of knowledge, attitude and practice.

\section{Study Location}

The study was conducted at three secondary schools which offered Form Six education in the Baling district, Kedah, which were Sekolah Menengah Kebangsaan (SMK) Kuala Ketil, SMK Kuala Pegang, and SMK Baling. The Baling district is one of 12 districts located in the state of Kedah and is the second largest district. Baling has an area of about 1530 sq. $\mathrm{km}$. Baling is also adjacent to or bordering Sik and Kuala Muda in the west, bordering Perak and Thailand in the east, and Kulim in the south.

\section{Study Sampling and Instrument}

The total population of students studying in Form Six in the Baling district, Kedah, was 226 people. The number of students in the Baling district randomly selected as samples was 144 students from three schools in the Baling district,
Kedah. The total of 144 taken was based on the table for determining sample size by Krejcie \& Morgan (1970). Of the 144 school students, the study sample consisted of 41 male students and 103 female students. This is because the population of Form Six students in the study area was comprised mostly of female students. In this case, it was not possible to determine a balanced sample selection. This is in line with Bakar's (2007) opinion that the numbers of male and female students do not necessarily have to be balance and it depends on the data obtained during data collection activities.

The study instrument used was a questionnaire form and were passed through expert validation from three lecturers at UPSI while content validity was done among three UPSI students to improve the questionnaire. The questionnaire consisted of five sections, namely Section A, B, C, D and E (see Table 1). Section A focuses on respondents' background, such as gender, academic stream, school name, race, parental education level, and water-saving information. Section B involves knowledge of water-saving. Section C regards attitude towards water-saving, and Section $\mathrm{D}$ describes respondents' water-saving practice. Section E is about respondents' comments and suggestions on the issues studied.

The items in this questionnaire were measured using a Likert scale, ranging from score of 1 to 5 . The Likert scale was used in this study to assess individuals' reactions using several assessment statements of either positive or negative. The 5-point Likert scale used for knowledge and attitude related to water-saving was $1=$ Strongly Disagree, $2=$ Disagree, $3=$ Strongly Agree, $4=$ Agree, and $5=$ Strongly Agree. Water-saving practice was measured using another Likert scale of $1=$ Never, $2=$ Occasionally, 3 = Sometimes, $4=$ Frequently, and $5=$ Very often. Water-saving knowledge, water-saving attitude and water-saving practice were evaluated based on the data collected by this questionnaire. A pilot study on the questionnaire form had earlier been conducted to assess the reliability of the study variables based on the Cronbach's Alpha score, as presented by Bond \& Fox (2015). Table 2 shows the reliability values of the water-saving study items among school students in the Baling district, Kedah. 
Table 1. Distribution of Questions in the Study Instrument Questionnaire

\begin{tabular}{|c|c|c|c|c|}
\hline Section & Aspects & Number of Items & Question Number & Source of Item \\
\hline $\mathrm{A}$ & $\begin{array}{l}\text { Respondent } \\
\text { background }\end{array}$ & 6 items & $1-6$ & Built according research need \\
\hline B & $\begin{array}{l}\text { Water saving } \\
\text { knowledge }\end{array}$ & $\begin{array}{l}20 \text { items (5-point } \\
\text { Likert scale) }\end{array}$ & $\begin{array}{l}1,2,8,9,10,11,12,15,17 \& 20 \\
3,4,5,7,14 \& 16 \\
6 \& 13 \\
19 \\
18\end{array}$ & $\begin{array}{l}\text { Built according research need } \\
\text { Mariapan (2018) } \\
\text { Mariapan (2018) } \\
\text { Mokmin \& Ithnin (2016) } \\
\text { Dworak et al. (2007) }\end{array}$ \\
\hline $\mathrm{C}$ & $\begin{array}{l}\text { Water saving } \\
\text { attitude }\end{array}$ & $\begin{array}{l}20 \text { items (5-point } \\
\text { Likert scale) }\end{array}$ & $\begin{array}{l}1,8,9,10,11,12,13,14,15,16 \\
17,18,19 \& 20 \\
2,3,4,5,6 \& 7\end{array}$ & $\begin{array}{l}\text { Built according research need } \\
\text { Mariapan (2018) }\end{array}$ \\
\hline $\mathrm{D}$ & $\begin{array}{l}\text { Water saving } \\
\text { practice }\end{array}$ & $\begin{array}{l}20 \text { items (5-point } \\
\text { Likert scale) }\end{array}$ & $\begin{array}{l}16,17,18,19 \& 20 \\
1,2,3,4,5,6,7,8,9,10,11,12 \\
13,14 \& 15\end{array}$ & $\begin{array}{l}\text { Built according research need } \\
\text { Mariapan (2018) }\end{array}$ \\
\hline
\end{tabular}

Table 2. Reliability Value of the Study Variables

\begin{tabular}{clccl}
\hline Section & Variable & Number of Items & Cronbach's Alpha Score & Reliability \\
\hline B & Knowledge & 20 & .944 & Very good \\
C & Attitude & 20 & .856 & Good \\
D & Practice & 20 & .896 & Good \\
\hline
\end{tabular}

The focus of this article's discussion is to identify the level of knowledge, attitude, and practice of school students regarding watersaving. The statistical data analysis clearly showed the frequency of the findings through the mean and percentage values of the level of knowledge, attitude, and practice of watersaving. Not only that, in this study, a $t$-test inference analysis was conducted to assess the existence of significant differences between certain groups, namely students' gender towards the variables being studied, such as knowledge, attitude and practice of water-saving. This study also examined the relationship between knowledge and water-saving attitude towards water-saving practice among school students. A significant level of $p<.05$ was used as the benchmark for the Pearson correlation, $r$, method.

\section{FINDINGS AND DISCUSSION Findings}

SMK Baling had the most respondents in this study with 70 people (48.6\%). The art stream represented the highest number of respondents, which was 142 people (98.6\%). In addition, the number of respondents by gender showed that the number of males was less than the females. The number of female respondents was 103 people $(71.5 \%)$ while the number of male respondents was 41 people (28.5\%). A majority involved in this study were Malays with 135 people $(93.8 \%)$, three people $(2.1 \%)$ were Chinese, three people were Indian $(2.1 \%)$, and the other respondents were Siamese with also three people (2.1\%). Most parents had a highest education level of Sijil Pelajaran Malaysia (SPM) with 65 people $(45 \%)$ and only a small number of parents whose highest level of education was a doctorate, only one person $(.7 \%)$.

\section{Analysis of the Levels of Knowledge, Attitude and Practice of Water-Saving Among Students}

A descriptive analysis method to see the scores for mean, standard deviation and level of variables according to the respondents was used in this section. The analysis in Table 3 found that the level of knowledge was high in general $(M=$ $4.03, S P=.354)$. Therefore, it can be concluded that most students had a great deal of knowledge regarding water-saving.

Table 3. Levels of Knowledge, Attitude and Practice of Water-Saving Variables

\begin{tabular}{|c|c|c|c|c|c|c|c|c|c|}
\hline \multirow{2}{*}{ Variable } & \multicolumn{2}{|c|}{ Low Level } & \multicolumn{2}{|c|}{ Moderate Level } & \multicolumn{2}{|c|}{ High Level } & \multirow{2}{*}{ Mean } & \multirow{2}{*}{$S D$} & \multirow{2}{*}{ Level } \\
\hline & $N$ & $\%$ & $N$ & $\%$ & $N$ & $\%$ & & & \\
\hline Knowledge & 0 & 0 & 21 & 14.6 & 123 & 85.4 & 4.03 & .354 & High \\
\hline Attitude & 0 & 0 & 61 & 42.4 & 83 & 57.6 & 3.79 & .444 & High \\
\hline Practice & 1 & .7 & 104 & 72.2 & 39 & 27.1 & 3.45 & .460 & Moderate \\
\hline
\end{tabular}


Analysis of the Differences in the Levels of Knowledge, Attitude and Practice towards Water-Saving Based on Gender

A $t$-test inference analysis was used in this study to assess the existence of significant differences of certain groups, which was the gender of the students towards the variables being studied, namely knowledge, attitude, and practice of water-saving. In order to determine the difference between male and female students' knowledge of water-saving, a null hypothesis was developed and tested.

The hypotheses tested are $H_{0}(1)$ : There is no significant difference in knowledge of water-saving based on gender among students. The level with a significance that is perceived and referred to in the $t$-test was $p<.05$. When the standard deviation value for a group is larger than and at a level of $p<.05$, then it can be said that there is a difference between male and female (Mariapan, 2018).

Based on this study, the differential analysis between male and female in terms of knowledge as represented in Table 4 showed that there was no difference in the knowledge variable between male $(M=4.02, S D=.39, N=41)$ and female $(M=4.04, S D=.34, N=103)$ where $(t$ $=-.27, d f=142, p>.05)$. This implies that the null hypothesis stating that there is no significant difference in knowledge of water-saving based on gender among students is accepted (failure to reject). This is because male and female students obtained the same education and information about water sources or water-saving at school, resulting in no difference in terms of the level of knowledge between male and female.
Analysis of the Relationships Between Knowledge, Attitude towards Water-Saving Practice Among Form Six Students

The analysis that was used to determine the relationship between knowledge, attitude and practice of water-saving among school students in the Baling district, Kedah, was conducted using the Pearson correlation coefficient analysis. This analysis was performed to test the $H_{0}(4)$ and $H_{0}(5)$ hypotheses. The construction of the research hypotheses was based on the third research question, which was "is there a relationship between the knowledge and practice of water-saving among students?" The construction of this test was performed to test the hypothesis $H_{0}(4)$ : There is no significant relationship between the level of knowledge and water-saving practice.

Based on Table 5, the relationship between the knowledge and practice of watersaving among Form Six students in the Baling district, Kedah, was moderate. The level of knowledge on water-saving $(r=.515)$ showed a moderately significant and positive relationship with water-saving practice. Not only that, the level of knowledge of water-saving had a moderate precision correlation of $p<.01$. Therefore, students' knowledge of water-saving practice remained at a moderate level. Based on the finding of this Pearson's correlation analysis, the null hypothesis of $H_{0}(4)$, stating that there is a significant relationship between the level of knowledge and practice of water-saving among Form Six students is rejected. Therefore, it can be explained that the level of knowledge of watersaving had a significant or close relationship with water-saving practice.

Table 4. Differential Analysis of Students' Gender towards the Knowledge, Attitude and Practice of Water-Saving Variables

\begin{tabular}{llrccccc}
\hline Variable & Gender & $\boldsymbol{N}$ & Mean & $\boldsymbol{S D}$ & $\boldsymbol{d} \boldsymbol{f}$ & $\boldsymbol{t}$ & $\boldsymbol{p}$ \\
\hline Knowledge & Male & 41 & 4.02 & .39 & 142 & -.27 & .78 \\
& Female & 103 & 4.04 & .34 & & & \\
Attitude & Male & 41 & 3.79 & .48 & 142 & -.05 & .96 \\
& Female & 103 & 3.80 & .43 & & & \\
Practice & Male & 41 & 3.45 & .49 & 142 & -.03 & .97 \\
& Female & 103 & 3.45 & .45 & & & \\
\hline
\end{tabular}

Table 5. Correlation Test of Knowledge and Attitude towards the Practice Related to Water-Saving Among Form Six Students

\begin{tabular}{lcc}
\hline \multirow{2}{*}{ Variable } & \multicolumn{2}{c}{ Practice } \\
\cline { 2 - 3 } & $\boldsymbol{r}$ & $\boldsymbol{p}$ \\
\hline Knowledge & $.515^{* *}$ & .000 \\
Attitude & $.596^{* *}$ & .000 \\
\hline * Significance at level $p<.05$ & &
\end{tabular}




\section{Discussion}

The findings of analysis of the levels of knowledge, attitude, and practice of water-saving among school students show that most students had a great deal of knowledge regarding watersaving in line with those of previous studies that indicate that knowledge is at a high level, as conducted by Dean et al. (2016); Samaltani \& Christidou (2013); Wang et al. (2019); and Mariapan et al. (2018), who discovered very similar findings to this study. The results of this study conclude that students obtained a high level of knowledge of water-saving through educational application. Educational application through curriculum and co-curriculum related to water-saving has enabled students to have a high level of knowledge in water-saving. For example, educational application is through certain subjects, such as moral education, civics, geography, biology, and other subjects related to water-saving knowledge. Not only that, schools which take their own initiative by conducting water education programmes generally provide students with a lot of knowledge input regarding water-saving. However, the findings of a study by Mokmin \& Ithnin (2016) found that students' knowledge was still at a moderate level in terms of water-saving overall, even though the students were often exposed visually to water-saving practice through mass media or through formal education at school. In addition, a study by Hao, Wang, Chen, Jiang, \& Yin (2010) pointed out that knowledge related to water-saving was still generally low because these students were not aware of the importance and effort made by the authorities regarding water-saving practice.

Furthermore, based on Table 3, the findings regarding the level of water-saving attitudes of the students was also high $(M=3.79, S P=.444)$. The attitude of the Form Six students in the Baling district, Kedah, towards water-saving was good and very encouraging. Most of the students gave positive feedback based on the questions posed in the water-saving questionnaire forms. Therefore, it can be concluded that the students still care about and are aware of saving water in their daily lives. The findings of this study are in line with the findings of the previous studies conducted by Wang et al. (2019) and Mariapan et al. (2018), which showed that students still reacted positively towards saving water in their daily lives. The good and positive attitude of the students towards water-saving was due to the success of education that emphasised watersaving topics in subjects at school as well as the role of well-educated parents in educating students to be more concerned with watersaving.

Meanwhile, the level of water-saving practice among Form Six students in the Baling district, Kedah, showed a moderate level $(M=$ $3.45, S P=.460$ ). The results of the study found that $72.7 \%$ of the students practiced watersaving at a moderate level while $27.1 \%$ were at a high level and .7\% were at a low level. It can be concluded that students were still not aware of practicing water-saving in their daily activities. Not only that, most students were not committed to practicing water-saving because they believed water-saving practice was not important and that the country was rich in water resources. Students were also very reluctant to save water as they would only practice water-saving if the situation was really demanding or they were asked to by their parents. This finding is further supported by the results of the studies conducted by Leng et al. (2013); Mokmin \& Ithnin (2016); and Mariapan (2018) stating that water-saving practice remained at a moderate level since there were some students who were still lacking in practicing water-saving in their daily activities. Most students thought that it was unnecessary to save water as Malaysia was still rich in water resources. Not only that, the students thought it was not important to practice water-saving because of the poor level of awareness and motivation to use water sustainably.

In order to determine the difference in water-saving attitude between male and female students, a null hypothesis was developed and tested. The hypothesis of the study is $H_{0}(2)$ : There is no significant difference in attitude towards water-saving based on gender among students. In this study, there was no significant difference between male $(M=3.79, S D=.48, N$ $=41)$ and female $(M=3.80, S D=.43, N=103)$ where $(t=-.05, d f=142, p>.05)$. Thus, the null hypothesis stating that there is no significant difference in attitude towards water-saving based on gender among the students is accepted (failure to reject). The result of this study was also because there were female and male students who received the same education and information on water resources or water-saving 
at school, resulting in no difference in the level of attitude between male and female. However, the results of this study are contrary to the previous study by Mariapan et al. (2019), which showed that there was a significant difference in water usage attitude involving male and female students. The findings of their study showed that there was a difference in the attitude towards water usage between female and male students. Not only that, female students tended to be more positive towards water usage than male students. Kilic \& Dervisoglu (2013) also stated that the attitude of female students towards water-saving was higher than the male students. Therefore, the level of attitude towards water-saving by gender in the Baling district, Kedah, was not significantly different between male and female students and appeared to be different than the findings of previous studies.

In order to determine the difference in water-saving practice involving male and female students, a null hypothesis was developed and tested. The hypothesis of the study is $H_{0}(3)$ : There is no significant difference in the practice of water-saving based on gender among students. The results showed that there was no significant difference between male $(M=3.45, S D=.49$, $N=41)$ and female $(M=3.45, S D=.45, N=$ 103) where $(t=-.03, d f=142, p>.05)$. Based on this analysis, the null hypothesis explaining that there is no significant difference in the practice of water-saving based on gender among the students is accepted (failure to reject). This is because the male and the female students obtained the same exposure of education at school, such as in water-saving programmes conducted by the school management or other authorities. Not only that, the male and female students were also used to water-saving practice as they took part in daily routines, such as washing clothes, dishes, bathing, washing school shoes and so on. The results of this study were in line with the results of the previous study conducted by Mariapan et al. (2019), which also mentioned that there was no difference in water-saving practices between male and female. However, the findings of the studies by Adams (2014) and Damanhouri et al. (2012) stated that the female gender had lower awareness in water-saving practice than male. Overall, there were no significant differences between the male and female students in the Baling district, Kedah, in terms of water-saving practice.

Therefore, the findings of this study are in line with the findings by Mokmin \& Ithnin (2016) and Mariapan et al. (2018) on the existence of a significant positive relationship between students' level of knowledge of and practice of water-saving. Overall, it can be concluded that an increase in students' knowledge of water-saving will enhance students' practice of maximising water-saving when carrying out activities that involves using water.

In addition, this study also analysed the relationship between attitude and practice of water-saving among school students in the Baling district, Kedah. This analysis was conducted to test the hypothesis of $H_{0}(5)$, based on the third research question: "is there a relationship between the attitude and the practice of water-saving among school students?" The $H_{0}(5)$ hypothesis to be tested is as follows: There is no significant relationship between attitude and the level of water-saving practice. The result of the Pearson's correlation that had been analysed revealed that there was a moderate and significant relationship between the level of water-saving attitude and practice $(r=.596)$. Therefore, the level of watersaving attitude showed a moderate correlation of $p<.01$. According to this Pearson's correlation analysis, the null hypothesis of $H_{0}(5)$ found no significant relationship between the level of water-saving attitude and practice among students. This indicates that students' positive attitudes towards water-saving will increase students' practice of saving water during their daily lives. Therefore, it can be concluded that the higher and more positive the level of watersaving attitude, the higher the level of watersaving practice is among Form Six students in the Baling district, Kedah.

Ironically, this finding is contradictory to a study conducted by Mariapan et al. (2018), which stated that the level of water usage attitude of upper secondary school students had a poor relationship with the level of sustainable water usage. This is because these students were still in the learning process and there was still a lot to learn about water-saving compared to the older Form Six students in terms of managing water sustainably. Therefore, this led to the differences in water-saving attitude and water-saving practice among Form Six students in the Baling district, Kedah, which has a moderate positive 
relationship as compared to the relationship between water usage attitude and the level of sustainable water usage practice among Form Four students in Utara Kinta, Perak, which had a weak relationship.

\section{CONCLUSION}

Overall, the level of knowledge regarding water-saving was at a high level among students, especially the Form Six students in the Baling district, Kedah. The results of this study conclude that the students had gained an extensive knowledge in water-saving through formal and informal educational application. Not only that, the attitude of the students was also at a high level. This indicates that the students were still concerned with and had a high level of responsibility in saving water in their daily lives. However, the students' practice was at a moderate level, which suggests that most of the students were not as committed to practicing water-saving because they considered it unimportant and that Malaysia was rich in water resources. The results of the $t$-test analysis showed that there were no significant differences in the knowledge, attitude, and practice regarding water-saving between male and female students.

The results of the correlation analysis conducted have shown that there was a moderate relationship between the knowledge and practice variables. Thus, this describes that the students' knowledge regarding water-saving practice was still good, but they had not reached the maximum level of water-saving in their daily lives. While there was also a moderate relationship between attitude and practice, which indicates that the students' attitude towards water-saving practice was still good despite not reaching the maximum. Therefore, the awareness of water-saving among school students needs to be further enhanced as they are the generation that will lead and develop the country in the future. The sustainability of the environment is highly dependent on them and how they can manage these resources and the environment efficiently and effectively.

\section{REFERENCES}

Adams, E.A. (2014). Behavioral attitudes towards water conservation and re-use among the United States public. Resources and Environment, 4(3), 162-167. http://article. sapub.org/10.5923.j.re.20140403.04. html.

Ajzen, I. (2005). Attitudes, personality, and behaviour $\left(2^{\text {nd }}\right.$ ed.). England: Open University Press.

Ali, A. (2019, 20 November). Kempen jimat air dalam kalangan pelajar. [Water conservation campaign among students]. Sinar Harian. https://www.sinarharian. com.my/article/14138/EDISI/MelakaNS/Kempen-jimat-air-dalam-kalanganpelajar.

Aprile, M. C., \& Fiorillo, D. (2017). Water conservation behavior and environmental concerns: Evidence from a representative sample of Italian individuals. Journal of Cleaner Production, 159, 119-129. https:// doi.org/10.1016/j.jclepro.2017.05.036.

Aydogdu, B., \& Cakir,A. (2016). An investigation of middle school students' attitudes and awareness of water use. International Journal of Environmental and Science Education, 11(16), 9520-9536. http:// www.ijese.net/makale/1185.html.

Bakar, B. A. (2007). Kaedah analisis data penyelidikan ilmiah. [Methods for analyzing scientific research data]. Kuala Lumpur: Utusan Publications \& Distributors Sdn Bhd.

Bond, T. G., \& Fox, C. M. (2015). Applying the Rasch Model: Fundamental measurement in the human sciences ( $3^{\text {rd }}$ ed.). Mahwah, NJ: Lawrence Erlbaum Associates Publisher.

Briere, C. S. (2010). Gender and environmental treaties: Is female empowerment the key to environmental protection? (Master Thesis, Georgetown University). https:// repository.library.georgetown.edu/ bitstream/handle/10822/553666/briereCa.

Çoban, G. U., Akpınar, E., Küçükcankurtaran, E., Y1ldı, E., \& Ergin, O. (2011). Elementary school students' water awareness. International Research in Geographical and Environmental Education, 20(1), 6583. https://doi.org/10.1080/10382046.201 $\underline{1.540103}$. 
Damanhouri, M. S., Al-Saleem, B. A., \& Al-Ali, Y. Y. (2012). Level of water awareness at some Jordanian university's students. Journal of Social Sciences, 8(3), 454-458. https://doi.org/10.3844/ jssp.2012.454.458.

Dean, A. J., Fielding, K. S., \& Newton, F. J. (2016). Community knowledge about water: who has better knowledge and is this associated with water-related behaviors and support for water-related policies? PloS ONE, 11(7), e0159063. https://doi. org/10.1371/journal.pone.0159063.

Dworak, T., Berglund, M., Laaser, C., Strosser, P., Roussard, J., Grandmougin, B., \& ... Montesinos, P. (2007). European water saving potential (Part 1-report) (ENV.D.2/ ETU/2007/0001r). Berlin. https://www. ecologic.eu/13210.

Hablemitoglu, S., \& Ozmete, E. (2010). Sustainable water management: A case study on saving behaviour of Turkish women for domestic water usage. European Journal of Social Sciences, 12(3), 447-456.

Hadi, A. S. (2010). Urbanisasi di Malaysia: Mengaitkan kepelbagaian proses ke bentuk perbandaran. [Urbanization in Malaysia: Relating the diversity of processes to urbanization]. Malaysian Journal of Environmental Management, 11(2), 21-31. http://journalarticle.ukm. my/2354/.

Hao, Z. J., Wang, Y., Chen, Y. S., Jiang, L., \& Yin, C. T. (2010). Current situation evaluation and systematic analysis on water saving knowledge, awareness, and behaviour - A case study of high school students in Beijing. Journal of Natural Resources, 25(9), 1618-1628. https://doi. org/10.11849/zrzyxb.2010.09.021.

Kelly, D., \& Fong, D. (2015, 17-20 August). Water conservation: The implications of user awareness, attitude, and behaviour. Paper presented at the $41^{\text {st }}$ International Symposium of CIB W062 Water Supply and Drainage for Buildings, Beijing University of Civil Engineering and
Architecture, China.

Keramitsoglou, K. M., \& Tsagarakis, K. P. (2011). Raising effective awareness for domestic water saving: evidence from an environmental educational programme in Greece. Water Policy, 13(6), 828-844. https://doi.org/10.2166/wp.2011.103.

Kilic, D. S., \& Dervisoglu, S. (2013). Examination of water saving behavior within framework of theory of planned behavior. International Journal of Secondary Education, 1(3), 8-13. https:// doi.org/10.11648/j.ijsedu.20130103.11.

Krejcie, R. V., \& Morgan, D. W. (1970). Determining sample saiz for research activities. Educational and Psychological Measurement, 30(3), 607-610. https://doi. org/10.1177/001316447003000308.

Lambert, L. (2010). Leardership capacity for lasting school improvement. Kuala Lumpur: Institut Terjemahan Negara Malaysia Berhad.

Lamm, A. J., Lundy, L. K., Warner, L., \& Lamm, K. W. (2016). Associating importance with behavior: Providing direction for water conservation communication. Journal of Applied Communications, 100(3), 44-56. https://doi.org/10.4148/1051-0834.1229.

Leng, P. W. Weng, C. N., Hui, L. C., \& Jahi, J. Md. (2013). Tingkah laku pengguna air domestik pada penggunaan air mengikut kawasan. [Domestic Water Consumer Behavior on Water Consumption by Area]. In R. Hashim \& A. G. Ismail (Eds.). Prosiding Seminar Hasil Penyelidikan Sektor Pengajian Tinggi Ke-3. Putrajaya: Kementerian Pendidikan Malaysia, pp. 1239-1247.

Loughland, T., Reid, A., Walker, K., \& Petocz, P. (2003). Factors influencing young people's conceptions of environment. Environmental Education Research, 9(1), 3-19. https://doi. org/10.1080/13504620303471.

Mariapan, U. (2018). Amalan penggunaan air secara lestari: Kajian kes dalam 
kalangan pelajar tingkatan empat di daerah Kinta Utara, Perak. [Sustainable water use practices: A case study among Form 4 students in the North Kinta district of Perak]. (Master Thesis, Universiti Pendidikan Sultan Idris). https://ir.upsi. edu.my/detailsgphp?det $=3953$ \&highlig $\mathrm{ht}=$ Amalan\%20penggunaan $\% 20$ air $\% 20$ secara $\% 20$ lestari:\%20Kajian $\% 20 \mathrm{kes} \% 20$ pelajar\%20tingkatan $\% 20$ empat $\% 20$ daerah $\% 20$ Kinta $\% 20$ Utara, $\% 20$ Perak.

Mariapan, U., Mahat, H., \& Nayan, N. (2018). Kajian penggunaan air secara lestari dalam kalangan pelajar sekolah menengah. [Sustainable water usage among secondary school students]. Geografi, 6(1), 31-40. https://ejournal.upsi.edu.my/ index.php/GEOG/article/view/2077.

Mariapan, U., Mahat, H., \& Nayan, N. (2019). Peranan jantina terhadap amalan penggunaan air secara lestari: Kajian kes dalam kalangan pelajar tingkatan empat di Daerah Kinta Utara Perak, Malaysia. [Gender roles in sustainable water usage practices: A case study among form four students in Northern Kinta District, Perak]. Sains Humanika, 11(2), 57-63. https://doi.org/10.11113/sh.v11n2.1454.

Marinoski, A. K., Rupp, R. F., \& Ghisi, E. (2018). Environmental benefit analysis of strategies for potable water savings in residential buildings. Journal of Environmental Management, 206, 28-39. $\quad$ https://doi.org/10.1016/j. jenvman.2017.10.004.

Ministry of Education Malaysia. (2015). Buku teks Kurikulum Standard Sekolah Menengah Geografi (KSSM) tingkatan 2. [Geography text book Form 2 High School Standard Curriculum]. Johor Bahru, Johor: IMS Books Trading Sdn. Bhd.
Mokmin, M., \& Ithnin, H. (2016). Tahap kesedaran dan pengamalan tip penjimatan air dalam kalangan pelajar tingkatan enam di SMK Sultan Abdul Aziz, Kuala Selangor, Selangor. [Awareness level and water saving tip practice among form six students SMK Sultan Abdul Aziz, Kuala Selangor, Selangor]. Geografi, 4(2), 2127. https://ejournal.upsi.edu.my/index. php/GEOG/article/view/1931.

Onyenankeya, K., Caldwell, M., \& Okoh, A. (2015). Water conservation and culture of indifference among college students: The nexus of descriptive norms. Journal of Human Ecology, 52(1-2), 15-25. https:// doi.org/10.1080/09709274.2015.1190692 6 .

Sadik, F., \& Sadik, S. (2014). A study on environmental knowledge and attitudes of teacher candidates. Procedia Social and Behavioral Sciences, 116, 2379-2385. https://doi.org/10.1016/j. sbspro.2014.01.577.

Samaltani, D., \& Christidou, V. (2013). Water conservation in the nursery school. Global NEST Journal, 15(3), 421-429. https:// doi.org/10.30955/gnj.000779.

Wang, Y.-H., Chang, M.-C., \& Liou, J.-R. (2019). Effects of water-saving education in Taiwan on public water knowledge, attitude, and behavior intention change. Water Policy, 21(5), 964-979. https://doi.org/10.2166/wp.2019.173.

Yeap, C. H., Wahyuni, Khar, T. N., Cheah, U. H., \& Devadason, R. P. (2007). Development of a questionnaire to assess student's perceptions in values-based water education. Malaysian Journal of Educational Technology, 10(1), 39-55. 